\title{
UNDERSTANDING EFL STUDENTS' USE OF LISTENING STRATEGIES IN WATCHING ENGLISH CAPTIONED MOVIES
}

\section{Ha Dinh Nhu Nguyen}

Article History

Received: August 3, 2020

Accepted: August 25, 2020

Published: September 30, 2020

\section{Keywords}

English captioned movies, listening skills, listening strategies, non-English majors, English as a Foreign Language

\author{
HUTECH University, Institute of Technical Education (ITE), Vietnam \\ Email:nguyenhahitc@gmail.com
}

\begin{abstract}
Through the years, investigation into English captioned movies has been the subject of many studies in language teaching and learning. Most of these studies have found that listening strategies play a crucial part in enhancing students' listening skills. Focusing on the same subject but with a new perspective, this research aimed at exploring the frequency use of listening strategies in watching English captioned movies in five general English classes at Ho Chi Minh City Industry and Trade College (HITC). One hundred and fifty college freshmen participate in answering the questionnaire and twenty-five students in responding the semi-structured interview questions. The data gained from the questionnaire was analyzed by SPSS in terms of descriptive statistics and ANOVA test. The results of the study indicated that a vast number of students employed listening strategies at different levels of frequency in which the cognitive strategy was used more frequently than meta-cognitive and socio-affective strategies. The results further proved that there was no significant difference of non-English majors' listening strategies in watching English captioned movies in terms of majors.
\end{abstract}

\section{INTRODUCTION}

Researchers like Ellis (1997) or Harmer (2007) have asserted that listening is one of the four basic skills of language learning, and it plays a major role in everyday communication. Morley (1991: p.81) highlights that "Listening is the most common communicative activity in daily life: we can expect to listen twice as much as we speak, four times more than we read, and five times more than we write". Moreover, Vandergrift (1999) argues that it will be against the naturalistic approach of acquiring a language and cause "cognitive overload" if learners are forced to produce the forms that they have not acquired yet. In other words, learners should receive input before switching to any other stage of language learning. Listening, then, provides them with input. According to Walker (2010), nevertheless, listening is seen as one of the most difficult skills and yet the most important to have. That is why English teachers must seek for some way to facilitate their learners' listening process.

Traditionally, listening activities were believed to consist of only some typical tasks such as dictation, cloze listening and multiple choice questions (Richards, 2008). These kinds of activities somehow cause boredom in a language classroom. Nowadays, with the support of technology, teachers are observed to be enabled and encouraged to apply innovative multimedia tools to their teaching, especially in teaching listening skills (Flowerdrew \& Miller, 2005). Baltova (1994) points out that movies are effective and powerful tools to attract viewers' attention and emotion and encourage them to improve listening skills for understanding the contents. Videos, as a result, become an extremely useful source of listening materials since it provides learners with both audio and visual input. Further than that, not only is the image added to the sound, but the captions can also be included to facilitate listening process. The controversy arises around this is whether the use of captions in a video can enhance learners' listening skills (Başaran \& Köse, 2013; Yang, 2014; Campbell, 2016). Although many studies have been conducted over this issue, the answer is still far from conclusive.

In Vietnam, listening skill has not been paid attention in most schools; as a consequence, teaching this skill is not effective (Nguyen, 2013). In most English classes, listening activities are organized and designed with simple tasks. Students are instructed to complete tasks by listening to recordings several times. However, with the trend of globalization and role of listening skills in communication, schools have been recently starting to install listening devices in classes with the support of public finance. Teachers are required to attend the training sessions of using new devices. With the emerge of technology, teaching listening periods are gradually changing with the variety of methods and strategies.

In terms of listening strategies, they are considered a motivation for learners to become successful in listening skills. Listening strategies are "strategies that listeners consciously or unconsciously use in order that they can understand, 
analyze and interpret the text" (Vandergrift, 2007, p.10). It is important to consider that the choice of listening strategies has an influence on listening competence. There are different strategies that learners can apply to do listening tasks. Whether the learners feel comfortable during listening periods depends on their choice of strategies.

More specifically, O'Malley and Chamot's (1990) have pointed out common strategies used by learners like metacognitive, cognitive and socio-affective listening strategies. Remarkably, meta-cognitive strategy is the process listeners use in order to comprehend what they are listening to. Besides, cognitive strategy is mental activities which help learners obtain new knowledge. Socio-affective strategy is conscious activities listeners choose to adjust their learning.

In general, based on the significance of English captioned movies and listening strategies, the objectives of this study endeavors to explore non-English majors' employment of listening strategies in watching English captioned movies in English class at a Ho Chi Minh based college in Vietnam. The following research questions are formulated:

1. What are the listening strategies in watching English captioned movies employed by non-English majors?

2. Is students' use of listening strategies in watching English captioned movies significantly affected by their majors? If yes, how?

\section{LITERATURE REVIEW}

Many researchers suggest listening strategies in various ways. Gilakjani and Sabouri (2016) suggests different strategies such as predicting, asking for clarification and using non-verbal cues. Oxford (1990) divides listening learning strategies into two main groups: direct and indirect strategies. Direct strategies are related to the processing of language such as vocabulary memory and form recognition. Indirect strategies involve solving problems about learning. Holden (2004) expresses that learns can understand what they hear if they recognize the effective ways of using strategies to deal with various tasks. O’Malley and Chamot's (1990) points out common strategies used by learners like meta-cognitive, cognitive and socio-affective listening strategies. They are chosen and discussed in details in this research as follows:

\section{Meta-cognitive listening strategy}

Metacognitive listening strategy includes processes of planning, monitoring, selective attention and evaluating (Vandergrift, 1999). Stein (1999) carefully defines this strategy is "the various tactics listeners use in order to comprehend or achieve whatever their goal might be" (p.22). Sheory and Mokhatari (2001) states that metacognitive strategy is used to plan specific actions to get a specific aim. Holden (2004) suggests that meta-cognitive listening strategy has highly positive influence on learners' listening skills. Wenden (1998) demonstrates that the metacognitive strategy is a basis step to build the character of learners. It means that the deployment of this strategy helps learners to achieve autonomy in education. Students become more active to manage and find out the best solutions to practise and reinforce what they have learned. For this kind of strategy, learners must make a plan for listening, analyzing the listening process dynamically and evaluating the outcomes through listening tasks. Learners can be aware of what specific strategies are as well as how and when they are used with metacognitive strategy.

\section{Cognitive listening strategy}

Richard (2008) defines, "cognitive strategy is mental activities related to comprehending and storing input in working memory or long-term memory for later retrieval" (p. 11). This strategy helps learners to obtain knowledge and link new knowledge with existing linguistic system. There are two categories of cognitive strategy: top-down and bottom-up strategy. Bottom-up strategy refers to using the information about sound, word meanings and semantic contents to understand of what is heard one step at a time (Brown, 2006:2). At first, learners recognize the words and then get the meaning by combining the words that they recognized earlier. Nunan (2010) states that learners must hear some sounds and then hold them in working memory long enough so that they can connect these sounds and interpret what they heard. Top-down strategy refers to the use of background knowledge about specific topics to understand the messages from recordings (Brown, 2006:2). The learners predict the meaning by using clues or hints from texts and combining them with background knowledge or familiar topics. By taking advantage of this strategy, learners can use schematic knowledge to support interpreting the sounds more effectively.

\section{Socio-affective listening strategy}

According to Vandergrift (1997), socio-affective strategy helps learners to corporate with their classmates and to draw attentions and clarification from teachers. Griffiths (2010: p.1) defines "socio-affective strategy is conscious activities chosen by learners to regulate their own language learning". This strategy has the potential to improve learners' motivation in learning as well as doing listening tasks. According to Flowerdew and Miller (2005), it can be used to enhance learners' learning and motive them to continue learning. Bacon (1992) divides socio-affective strategy into 
social strategy and affective strategy. In terms of social strategy, learners share the ideas to others in order that they can get the comprehension in listening. Savigon and Sysoyev (2002) give the name sociocultural strategy for social strategy. It helps the learners effectively corporate with others and understand the target culture and languages. Affective strategy refers to personal confidence during the listening process. It is also called self-motivated strategy (Dörnyei, 2003). This could help learners to handle their feelings, motivations or attitudes in learning listening skills.

In terms of captions, they are considered as subtitles and help people easily understand the contents of spoken languages. Danan (2004) refers captions to "teletext subtitles" as how they are understood in Europe. Additionally, according to Abdollapour (2014), captions are transcriptions of audio portions of television programs, appearing on the screen at the same time as the program". Vandergrift (2007) defined, "captions may be defined as redundant text that matches spoken audio signals and appears in the same language as the target audio" (p.97). Captions are "the onscreen text in the original language combined with a soundtrack in the same language" (Markham, Peter \& McCarthy, 2001).

Apparently, it is crucial to define the relationship between English captioned movies and listening skills. It is a fact that English movies have several benefits for teaching listening skills in terms of understanding and interpreting the speakers' messages. Lonergan (1984) gives evidence that learners are able to distinguish speakers' daily conversations and enhance necessary linguistic structures. Froehlich (1988) states that learners are able to confirm the information they hear from recordings by the captions appearing on the screen. Bird and Williams (2002) confirms that captions or subtitles help to increase learners' listening comprehension. Markham (1989) concludes that learners could improve their listening skills by watching captioned movies. Pujola (2002) proves that students who had problems in listening skills had improved their listening skills with captions surprisingly. In addition, Gildea, Miller and Wurtenberg (1990) shows that learners who do not usually watch English movies face difficulty in producing complex sentences in the second language. Mclornan and Guichon (2008) supports that the use of captions helps to improve listening comprehension skill. Listeners obtain higher scores in listening tests thanks to the access to captioned movies. Wang and Liu (2011) state that movies with captions help them improve pronunciation, vocabulary and cross-cultural communication ability.

Previous studies have shown that English movies with captions are effective for learning a second language. Some have been investigated to find out listening strategies that learners use to watch captioned movies (O'Malley et al., 1989; Rost \& Ross, 199; Graham \& Santos, 2015; Vandergrift, 2003). Other studies proved that meta-cognitive listening strategy helped students to develop listening comprehension, deal with listening activities and plan specific steps for listening periods (Dousti, 2013; Meng and Taib, 2006; Tavakoli et al., 2012; Liu, 2008; Bidabadi and Yamat, 2011). Some studies emphasized the frequency and usefulness of cognitive strategy in listening periods as well as helping students know how to take notes, guess the meanings, improve ability to scope with listening tasks and conscious actions while listening to a text (Chen et al., 2010; Vandergrift, 1997; Duong et al, 2019; Purnomowati, 2016). In terms of socio-affective strategy, Vandergrift (1997), Duong et al. (2019) and Purnomowati (2016) state that this strategy has the low use and helps students improve the cooperation with their teachers and classmates in listening periods. In a word, various studies have detected the learners' listening strategies in watching English captioned movies. However, most of these few investigations were pursued recently, which indicates that this topic is still new to researchers. Besides, these studies focus on English-majored students although it is clear that listening skills are a requisite subject in general English classes. That is one of the reasons why this study should be carried out to explore non-English majors' use of listening strategies in watching English captioned movies at HITC and any differences among non-English majors' listening strategies in watching English captioned movies in terms of majors.

Through all of the literature presented and discussed in the previous sections, the researcher finally came to the conceptual framework of the study which was described in the following diagram.

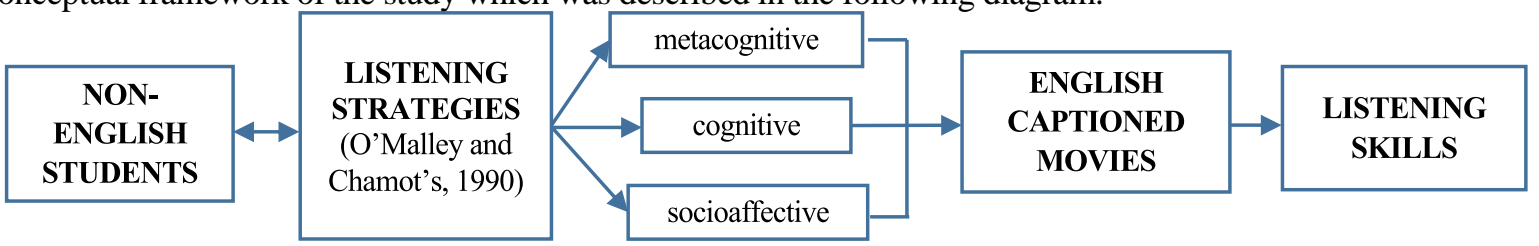

Figure 1. Conceptual framework of the students' listening strategies in watching captioned movies

\section{RESEARCH METHODS AND RESULTS}

\subsection{Research design}

In order to investigate the listening strategies of non-English majors, the mixed method design was used to collect and analyze the qualitative and quantitative data with a set of closed-ended questionnaire and semi-structured 
interview. This type of research, by nature, was concerned with the use of questionnaire to collect data from 150 students and the interview of 25 students from various faculties.

For this kind of study, the research was independent of the researcher. According to Creswell (2003: p.18), the quantitative research "employ strategies of inquiry such as experimental and surveys, and collect data in predetermined instruments that yield statistical data". As a fact, the findings from this kind of research could be used to predict, explain and confirm the given conceptual framework. In addition, the qualitative research was used to investigate the participants' viewpoint. Creswell (1994) states that it allows the researcher to spread a level of detail from high involvement in the actual experiences.

\subsection{Research setting and participants}

This research was carried out at Ho Chi Minh City based college, Vietnam. The participants of the present study consisted of 150 students who were the freshmen at the college. The participants' general information in Table 1 shows 6 main items, including gender, time for learning English, major, time for listening activity, time for watching movies with captions and kinds of movies.

Table 1. Participants' general information

\begin{tabular}{|c|c|c|c|c|}
\hline \multirow{2}{*}{ No. } & \multirow{2}{*}{\multicolumn{2}{|c|}{ Information }} & \multicolumn{2}{|c|}{$\mathrm{N}=150$} \\
\hline & & & No. of respondents & Percent \\
\hline \multirow{2}{*}{1} & \multirow{2}{*}{ Gender } & Male & 82 & $54.7 \%$ \\
\hline & & Female & 68 & $45.3 \%$ \\
\hline \multirow{2}{*}{2} & \multirow{2}{*}{ Time for learning English } & 7 years & 111 & $74 \%$ \\
\hline & & 11 years & 39 & $26 \%$ \\
\hline \multirow{5}{*}{3} & \multirow{5}{*}{ Major } & Information technology (IT) & 60 & $40 \%$ \\
\hline & & Mechanics (M) & 27 & $18 \%$ \\
\hline & & Accounting (A) & 30 & $20 \%$ \\
\hline & & Electronics $(\mathrm{E})$ & 18 & $12 \%$ \\
\hline & & Business administration (BA) & 15 & $10 \%$ \\
\hline \multirow{4}{*}{4} & \multirow{4}{*}{ Time for listening activity } & Less than an hour & 85 & $56.7 \%$ \\
\hline & & 1-3 hours & 61 & $40.7 \%$ \\
\hline & & 3-5 hours & 3 & $2.0 \%$ \\
\hline & & More than 5 hours & 1 & $0.7 \%$ \\
\hline \multirow{4}{*}{5} & \multirow{4}{*}{$\begin{array}{l}\text { Time for watching movies } \\
\text { with captions }\end{array}$} & Everyday & 74 & $49.3 \%$ \\
\hline & & 1-2 times/week & 52 & $34.7 \%$ \\
\hline & & 3-4 times/week & 15 & $10 \%$ \\
\hline & & More than 5 times/week & 9 & $6.0 \%$ \\
\hline \multirow{8}{*}{6} & \multirow{8}{*}{ Kinds of movies } & Action & 14 & $9.3 \%$ \\
\hline & & Documentary & 5 & $3.0 \%$ \\
\hline & & Cartoon & 80 & $53.3 \%$ \\
\hline & & Comedy & 35 & $23.3 \%$ \\
\hline & & Science-fiction & 7 & $13.3 \%$ \\
\hline & & Horror & 4 & $2.7 \%$ \\
\hline & & Musical & 3 & $2.0 \%$ \\
\hline & & Others & 2 & $1.3 \%$ \\
\hline
\end{tabular}

\subsection{Research instruments}

The instruments employed in the study included closed-ended questionnaire and semi-structured interview. Based on the related literature and research purpose, the questionnaire was designed in a multiple choice with a 5 Likert scale type ranging from 1 to $5(1=$ never, $2=$ seldom, $3=$ sometimes, $4=$ usually, $5=$ always $)$. The meanings of the mean scores for the students' listening strategy in watching English captioned videos were interpreted as follows: Never (11.80); Seldom (1.81-2.60); Sometimes (2.61-3.40); Usually (3.41-4.20) and Always (4.21-5.00). The questionnaire was divided into two parts with the total number of 26 items: personal information (6 items) and students' listening strategies in watching English captioned movies (20 items). In order to avoid the misunderstanding, the questionnaire was translated into Vietnamese. Students spent from 10 to 20 minutes to answer the questions. Then the data was calculated by SPSS software. Additionally, the Cronbach's Alpha was .843 which proved that the questionnaire was reliable. In addition, the semi-structured interview was taken advantage to gain an insight into evaluate the frequency of listening strategies students use to watch English captioned movies. 20 interviewees were selected for separate interviews. The 
interviews were also conducted in Vietnamese to ensure the accuracy of the interviewed data. The interviewees were labeled from S1 to S25. Each students had 25 minutes to answer the interview questions. Then the information collected from the interview was analyzed by using qualitative content analysis.

\subsection{Data collection and analysis}

Regarding data collection procedure, the researcher conducted two classes and then the colleagues at the Faculty helped to collect three classes. The researcher and colleagues were teaching at the college. The online questionnaire and interviews were delivered to their student and an instruction how to choose the multiple choices and answer the questions in the interview was explained in detailed. For the data analysis, the researcher employs SPSS 22.0 in which the descriptive statistic including Mean (M), Standard Deviation (SD), Percentages (P) and one-way Anova were processed, while the content analysis was employed to deal with qualitative data.

\subsection{Findings}

\subsubsection{Listening strategies in watching English captioned movies}

Table 2 showed that the frequency of using listening strategies was rather high $(\mathrm{M}=3.80 ; \mathrm{SD}=.707)$, which means that students used listening strategies rather frequently. Among items of listening strategies, the frequency of using cognitive listening strategy was the highest (Group 2: $\mathrm{M}=3.77 ; \mathrm{SD}=.713$ ). The next frequently-used strategy by students in watching captioned movies was meta-cognitive (Group 1: $\mathrm{M}=3.61 ; \mathrm{SD}=.824$ ). The least frequently used strategy was socio-affective (Group 3: $\mathrm{M}=3.51 ; \mathrm{SD}=.563$ ). Altogether, students tended to adopt flexible listening strategies when they watched English captioned movies.

Table 2. Listening strategies in English captioned movies

\begin{tabular}{clcc}
\hline \multirow{2}{*}{ No. } & \multirow{2}{*}{ Listening strategies } & M & SD \\
\cline { 3 - 4 } & & 3.61 & .824 \\
\hline 1 & Meta-cognitive & 3.77 & .713 \\
\hline 2 & Cognitive & 3.51 & .563 \\
\hline 3 & Socio-affective & $\mathbf{3 . 6 2}$ & $\mathbf{. 7 0 7}$ \\
\hline
\end{tabular}

Note: : mean; SD: Standard deviation

These data are analyzed and discussed descriptively as follows:

Meta-cognitive listening strategy

The questionnaire included 7 items to check students' frequency of using meta-cognitive listening strategy. As can be seen in Table 3, it is clear that students usually checked their understanding through listening activities (item 2.7: $\mathrm{M}=3.73$; $\mathrm{SD}=.759$ ). The results further revealed that students often prepared plans carefully to concentrate on captions (item 2.2: $\mathrm{M}=3.72 ; \mathrm{SD}=.836$ ). Moreover, students had a tendency to keep in minds prepared plans to watch captioned movies (item 2.5: $\mathrm{M}=3.64 ; \mathrm{SD}=.744$ ). Besides, students often prepared their mind to select specific information (item 2.4: $\mathrm{M}=3.59$; $\mathrm{SD}=.844$ ). In addition, students often reflected on their problems such key words that they did not understand (item 2.6: $\mathrm{M}=3.57$; $\mathrm{SD}=.862$ ). Students also clarified objectives of listening periods (item 2.1: $\mathrm{M}=3.55 ; \mathrm{SD}=.863$ ). However, students seemed to have a clear plan in their head for how they were going to listen (item 2.3: $\mathrm{M}=3.43$; $\mathrm{SD}=.862$ ).

Table 3. The frequency of using meta-cognitive listening strategy in English captioned movies

\begin{tabular}{cccc}
\hline \multirow{2}{*}{ No. } & Meta-cognitive listening strategy & \multicolumn{2}{c}{$\mathbf{N = 1 5 0}$} \\
\cline { 3 - 4 } & & $\mathbf{M}$ & SD \\
\hline 2.1 & I clarify the objectives of listening units. & 3.55 & .863 \\
\hline 2.2 & I prepare my mind to concentrate on captions. & 3.72 & .836 \\
\hline 2.3 & I have a clear plan in my head for how I am going to listen. & 3.43 & .862 \\
\hline 2.4 & I prepare my mind to select specific information. & 3.59 & .844 \\
\hline 2.5 & I keep in my mind on prepared plans to watch captioned movies. & 3.64 & .744 \\
\hline 2.6 & I reflect on my problems such as key words that I do not understand. & 3.73 & .862 \\
\hline 2.7 & I evaluate how much I can understand by doing listening tasks. & 3.61 & .759 \\
\hline & Total & .824 \\
\hline
\end{tabular}

Note: : mean; SD: Standard deviation

Concerning the data collected from the interview, $42.5 \%$ students who took part in the interview thought that metacognitive should be taught before watching captioned movies. For the reason why the meta-cognitive listening strategy was important for watching English captioned movies, most of the students thought that they needed to have specific 
steps to comprehend what they heard in each movie. In addition, they felt active to find out the solutions for their learning. Here are some of the obvious examples for the reasons for the importance of meta-cognitive listening strategy:

- Meta-cognitive listening strategy helps me formulate steps in order that I can find it easy to understand the movies. (S2)

- I can monitor and evaluate my listening thanks to meta-cognitive listening strategy. (S7)

- With the specific steps in this strategy, I can enhance my learning autonomy and solve unexpected problems easily. (S8)

- Meta-cognitive listening strategy helps me to evaluate my listening ability in order that I can change my listening styles for each lesson. (S14)

- Meta-cognitive listening strategy is important to me because I am lazy and I need to follow steps by steps so that I can understand the movies easily. (S15)

\section{Cognitive listening strategy}

Cognitive listening strategy was the most frequently used by students when watching English captioned movies $(\mathrm{M}=3.77 ; \mathrm{SD}=.713)$. As can be seen in Table 4, it was measured by 7 items. Among 7 items listed in cognitive strategies, students tended to guess the meanings based on the familiar captions more often (item 2.12: M=4.13; $\mathrm{SD}=.587$ ) and frequently guessed the meaning of words by connecting them with speakers' gestures. In addition, students frequently noticed the questions words in the contents (item 2.8: $\mathrm{M}=3.87 ; \mathrm{SD}=.739$ ) and tried to understand each word in captions (item 2.9: $\mathrm{M}=3.83 ; \mathrm{SD}=.740$ ). Besides, students also often predicted the contents of movies by titles (item 2.13: $\mathrm{M}=3.59 ; \mathrm{SD}=.724$ ). These items were comparatively higher than the rest on the list. The lowest frequency of using listening strategy was that students sometimes concentrated on main ideas first and then details of movies (item 2.12: $\mathrm{M}=3.53 ; \mathrm{SD}=.766$ ). However, students sometimes took notes of main and key words in each captioned movie (item 2.11: $\mathrm{M}=3.52 ; \mathrm{SD}=.792$ ).

Table 4. The frequency of using cognitive listening strategy in English captioned movies

\begin{tabular}{|c|c|c|c|}
\hline \multirow{2}{*}{ No. } & \multirow{2}{*}{ Cognitive listening strategy } & \multicolumn{2}{|c|}{$\mathbf{N}=150$} \\
\hline & & $\mathbf{M}$ & SD \\
\hline 2.8 & I notice the question words in the contents of movies. & 3.87 & .739 \\
\hline 2.9 & I try to understand each word in captions. & 3.83 & .740 \\
\hline 2.10 & I guess the meaning of words by connecting them with speakers' gestures. & 3.95 & .643 \\
\hline 2.11 & I take notes of main points and key words. & 3.52 & .792 \\
\hline 2.12 & I concentrate on main ideas first and then details. & 3.53 & .766 \\
\hline 2.13 & I predict the contents of movies by titles. & 3.59 & .724 \\
\hline 2.14 & I guess the meanings based on the familiar captions. & 4.13 & .587 \\
\hline & Total & 3.77 & .713 \\
\hline
\end{tabular}

Note: M: mean; SD: Standard deviation

With respect to the qualitative, the collected findings from the interview revealed that more than a half of students (59\%) agreed that cognitive listening strategy was the most important for watching English captioned movies. In addition, they also admitted that they usually used this strategy for watching captioned movies. Some of their responses are as follows:

- Among three strategies, I agree that cognitive listening strategy is the most useful for students to understand the movies. (S1)

- I focus on the captioned movies and try to connect new words with existing word system. (S3)

- I formulate learning habits such as guessing meanings and connecting characters' gestures with strange words. (S5)

- I often look at the title to practice guessing the contents of movies, then it helps me to listen to the captions easier. (S24)

- For new words, I often look at the speakers' body languages to guess the meaning and practice listening their pronunciation. (S25)

- When I hear some strange words, I usually write down and put them into my long-term memory. (S24)

Socio-affective listening strategy

Socio-affective listening strategy, with 6 measured items, was the last listening strategy mentioned in this study. As gleaned from Table 5, students used this strategy relatively often $(\mathrm{M}=3.51 ; \mathrm{SD}=.563)$. Among 6 items, students "try[ing] to relax themselves while they are watching the captioned movies" (item 2.20: $\mathrm{M}=4.19 ; \mathrm{SD}=.536$ ) and 
"always keep[ing] focused while watching the captioned movies" (item 2.49: $\mathrm{M}=4.18 ; \mathrm{SD}=.479$ ) were more often than the last ones. Besides, it was obvious that students usually asked classmates to work in pairs to solve difficult tasks after watching English captioned movies (item 2.16: $\mathrm{M}=4.07$; $\mathrm{SD}=.539$ ). In addition, students admitted that they usually "ask[ing] teachers questions they do not understand" (item 2.15: M = 3.98; SD = .561) and "ask[ing] teachers for feedback on their answers" (item 2.18: $\mathrm{M}=3.97$; $\mathrm{SD}=.595$ ). The item that students often used was "shar[ing] the answers to the classmates" (item 2.17: $\mathrm{M}=3.89$; $\mathrm{SD}=.667$ ).

Table 5. The frequency of using socio-affective listening strategy in English captioned movies

\begin{tabular}{cccc}
\hline \multirow{2}{*}{ No. } & Socio-affective listening strategy & N $=\mathbf{1 5 0}$ \\
\cline { 3 - 4 } & & $\mathbf{M}$ & SD \\
\hline 2.15 & I ask my teachers questions I do not understand. & 3.98 & .561 \\
2.16 & I ask my classmates to work in pairs to solve difficult listening tasks. & 4.07 & .539 \\
2.17 & I share the answers to the classmates. & 3.89 & .667 \\
2.18 & I ask my teachers feedback on what I do with listening tasks. & 4.97 & .595 \\
\hline 2.19 & I always keep focused while I am watching the movies. & 4.19 & .479 \\
2.20 & I try to relax myself while I am watching the movies. & 3.77 & .536 \\
\hline
\end{tabular}

Note: M: mean; SD: Standard deviation

Along with the aforementioned results, qualitative analysis from interview unfolded that students also agreed that socio-affective listening strategy was important when watching English captioned movies. They needed to have a supportive as well as relaxing environment at class. Some of the obvious examples were listed as follows:

- I feel relaxed and focusing on movies even though there are distractions. (S4)

- I feel secured when getting feedback as well as assistant from my teachers who help me to explain difficult phrases in captioned movies. (S9)

- Sharing answers and getting supports from classmates make me more confident to do listening tasks after each movie. (S18)

- I like to work in pairs when watching English captioned movies because it is not too noisy for me to complete the movies. (S13)

- Whenever I need a support to explain difficult words, I hope to see my teachers and classmates immediately. (S21)

- Working with other people to finish listening tasks, I feel comfortable and excited. (S10)

3.5.2. Differences in non-English majors' listening strategies in terms of majors

The results from one-way ANOVA in Table 6 indicated that there was no statistically significant difference in non-English majors' listening strategies ( $\mathrm{F}=.681$; Sig.=.606) in terms of majors. This means that although students were from different majors, they had similar listening strategies in watching English captioned movies.

Table 6. One-way ANOVA: Different in listening strategies in terms of majors

\begin{tabular}{|c|c|c|c|c|c|c|c|}
\hline \multirow{2}{*}{ Factors } & \multirow{2}{*}{ Sig. } & \multirow{2}{*}{$\mathbf{F}$} & \multicolumn{5}{|c|}{ M(SD) } \\
\hline & & & IT & $\mathbf{M}$ & $\mathbf{A}$ & $\mathbf{E}$ & $\overline{\mathbf{B A}}$ \\
\hline Listening strategies & .606 & .681 & $\begin{array}{l}3.84 \\
(.34)\end{array}$ & $\begin{array}{l}3.73 \\
(.39)\end{array}$ & $\begin{array}{l}3.83 \\
(.37)\end{array}$ & $\begin{array}{l}3.79 \\
(.37)\end{array}$ & $\begin{array}{l}3.71 \\
(.33)\end{array}$ \\
\hline
\end{tabular}

*The mean difference is significant at the .05 level

* Note: M: Mean; SD: Standard Deviation

The findings of the study have revealed some highlighted features of non-English majors' listening strategies in watching English captioned movies and differences in listening strategies in terms of majors.

Firstly, the findings of this study divulged that students used listening strategies which include meta-cognitive, cognitive and socio-affective strategies rather frequently. Regarding meta-cognitive listening strategy, the findings of the current study were consistent with those of Tavakoli et al. (2012); Sheory and Mokhatari (2001); Vandergrift (1999); Stein (1999); Wenden (1998); Ozeki (2000); Goh (1998) and Duong et al. (2019), who carefully pointed out the process of meta-cognitive and characters of learners. The findings of this study showed that students usually prepared plans in details for each listening task. They set up a careful process for listening activities. They had their own specific tactics as well as autonomous learning such as checking the understanding after each lesson, reflecting problems in during listening process and clarifying objectives of listening lessons. These findings were also partially confirmed by Holden (2004); Dousti (2013) and Meng and Taib (2006). In terms of cognitive listening strategy, the results were partially consistent 
with Chen et al. (2010); Vandergrift (1997); Duong et al. (2019) and Purnomowati (2016), who reported that the cognitive listening strategy was the most used by students. The findings showed that students became active to guess the meanings of words in each captioned movie, created the link between existing linguistic system and current knowledge, and positively dealt with difficulties in listening tasks. There was a similarity between the cognitive strategy expressed by Richard (2008), who defined that cognitive listening strategy related activities of comprehending and storing knowledge in working memory for later use. One unanticipated finding was that students (59\%) recognized cognitive listening strategy was the most important for English captioned movies. They admitted that this strategy was useful for watching English captioned movies. With regards to socio-affective listening strategy, the findings were in agreement with Vandergrift (1997)'s and Purnomowati (2016)'s findings which showed that socio-affective strategy supported learners to corporate with classmates and teachers. The current study found that students always collaborated with teachers and classmates during learning periods. They always asked classmates for pair works and teachers for feedback on their answers. Another important finding was that students always felt relaxed and focused on English captioned movies.

Secondly, the findings showed that majors did not affect listening strategies of non-English majors in watching English captioned movies. There are several possible explanations for this result. The first reason might be that students realized the important role of English captioned movies. Despite the fact that students have different majors, they have the same listening strategies in watching English captioned movies. With the findings from the study, it might be concluded that students could improve their listening skills by watching English captioned movies. The second reason could be that students were interested in English caption movies. Watching English captioned movies helped to reduce boredom and tiredness during 3 periods. As a result, they always had the same listening strategies in spite of different majors. Last but not least, it might be accepted that thanks to teachers' serious regulations for learning periods in class. All of the majors in the same class must follow lesson plans in which teachers set up specific strategies for each English captioned movie. It was a fact that the lesson plans were required in most of classes. It might be said that students usually follow serious steps in lesson plans, so they always have the same frequency of using listening strategies.

\section{DISCUSSION AND CONCLUSION}

The results of this study shed light on students' listening strategies in watching English captioned movies. One of the significant findings to emerge from this study was that the frequency of listening strategies that students used to watch English captioned movies was relatively high. Among listening strategies mentioned in this study, the most frequently used strategy by students was cognitive, followed by meta-cognitive and socio-affective. In terms of cognitive listening strategy, students tended to guessed meaning words in the contents, predicted the contents of movies as well as wrote down main points of the movies. With respect to meta-cognitive listening strategy, students always checked their understanding after watching English captioned movies, set up detailed plans and steps for listening periods and raised issues after each lesson. Relating to socio-affective listening strategy, students always tried to relax and keep focus on each English captioned movie as well as actively worked with classmates and teachers to do listening tasks.

The findings suggest several courses of action for the administrations, the teachers in charge of teaching general English and students in general English classes at HITC. For the administrations of HITC, they should either allow more time for the general English course or reduce the number of students in classes. Besides, they should allow the course to take place in well-equipped classrooms or laboratories. In particular, the administrations or the faculty should organize workshops, training courses, and demonstration classes related to the practice of teaching English captioned movies. Finally, the school and faculty should call for more research on this field. For the English teachers of HITC, they have to make sure that students fully understand the effectiveness of English captioned movies. Moreover, they should promote the interaction among students in the classrooms by creating a more supportive classroom environment. Last but not least, the teachers should design both in-class and out-of-class tasks with more activities for the students. To the students in general English classes, they should be aware of the importance and usefulness of captioned movies to improve listening skills and practice listening strategies to apply into various kinds of listening tasks effective.

However, the study was limited in several ways. First, the study was conducted on five general English classes which accounted for only a small proportion of the total classes at HITC. Therefore, the results of this study could not represent the whole situation at HITC. Second, the study focused on the first-year students; therefore, it did not provide a complete picture of attitudes of the second-year and last-year students. Last but not least, the study used the mixed-method with two instruments, including questionnaire and semi-structure interview. It will be better to use pre-test and post-test in order to obtain deep insights into the listening strategies used by HITC students. 


\section{REFERENCES}

Bacon, S. M. (1992). Authentic listening in Spanish: How learners adjust their strategies to the difficulty of the input. Hispania, 75(2), 398-412.

Baltova, I. (1994). Multisensory language teaching in a multidimensional curriculum: The use of authentic bimodal video in core French. The Canadian Modern Language Review, 56(1), 32-48.

Başaran, H., \& Köse, G. (2013). The Effects of Captioning on EFL Learners' Listening Comprehension. Procedia Social and Behavioral Sciences, 70(1), 702-208.

Bidabadi, F. \& Yamat, H. (2011). The relationship between listening strategies used by Iranian EFL freshman university students and their listening proficiency levels. English Language Teaching, 4(1), 26-32.

Bird, S. A. \& Williams, J. N. (2002). The effect of bimodal input on implicit and explicit memory: An investigation into the benefits of within-language subtitling. Applied Psycholinguistics, 23(4), 509-533.

Blake, R. (2005). Bimodal CMC: The glue of learning at a distance. CALICO Journal, 22(3), 497-511.

Brown, S. (2006). Teaching Listening. New York: Cambridge University Press.

Campbell, A. (2016). Subtitling for Mission Accomplishment: An Experimental Study of the Effect of Subtitling as a Task on Listening Comprehension for Learners of Military English for Specific Purposes (Unpublished master's thesis). Pablo de Olavide University, Spanish.

Chen, K. T., Lee, I. Y., \& Lin, C. (2010). EFL learners' uses of listening comprehension strategies and learning style preferences. The International Journal of Learning, 17(6), 245-255.

Chenoweth, N. A., Ushida, E., \& Murday, K. (2006). Student learning in hybrid French and Spanish courses: An overview of Language Online. CALICO Journal, 24(1), 285-314.

Danan, M. (2004). Captioning and subtitling: Undervalued language learning strategies. Meta, 49(1), 67-77.

Dörnyei, Z. (2003). Questionnaires in second language research: Construction, administration, and processing. Mahwah, NJ: Lawrence Erlbaum.

Dousti, H. (2013). The effect of metacognitive listening strategy training on EFL learners' listening sub-skills performance. International Journal of Applied Linguistics \& English Literature, 2(4), 50-55.

Duong, M. T., Tran, T. H. T \& Tran, Q. T. (2019). Eleventh graders' actual use of English listening learning strategies at Duong Van Duong high school. VNU Journal of Foreign Studies, 35(1), 114-130.

Ellis, R. (1997). Second Language Acquisition. Oxford: Oxford University Press.

Flowerdew, J. \& Miller, L. (2005). Second language listening: Theory and practice. Cambridge: Cambridge University Press.

Froehlich, J. (1988). German videos with German subtitles: A new approach to listening comprehension development. Die Unterrichtspraxis/Teaching German, 21(2), 199-203.

Garza, T. (1991) Evaluating the use of captioned video materials in advanced foreign language learning. Foreign Language Annals, 24(3), 239-258.

Gilakjani, A. P. \& Sabouri, N. B. (2016). A study of factors affecting EFL learner's reading comprehension skill and the strategies for improvement. International Journal of English Linguistics, 6(5), 180-187.

Gildea, P., Miller, G. A., \& Wurtenberg, C. L. (1990). Contextual enrichment by videodisc. In Don Nix \& Rand Spiro (Eds.). Cognition, education, Multimedia: Exploring ideas in high technology. Hillsdale, NJ, Lawrence Erlbaum Associates.

Graham, S. \& Santos, D. (2015). Strategies for second language listening: Current scenarios and improved pedagogy. Basingstoke: Palgrave.

Griffths, C. (2010). Strategies of successful language learners. Journal of English Language Studies, 1(3), 1-10.

Harmer, J. (2007). The Practice of English Language Teaching. Harlow: Longman.

Holden, W. R. (2004). Facilitating Listening Comprehension: Acquiring Successful Strategies. Bulletin of Hokuriku University, 28, 257-266.

Liu, H. J. (2008). A study of the interrelationship between listening strategy use, listening proficiency levels, and learning style. RARECLS, 5, 84-104.

Lonergan, J. (1984). Language and languages; study and teaching; audio-visual aids. Cambridge: Cambridge University Press.

Markham, P. (1989). The effects of captioned television video tapes on the listening comprehension of beginning, intermediate and advanced ESL students. Educational Technology, 29(10), 38-41. 
Markham, P., Peter, L., \& McCarthy, T. (2001). The effects of native language vs. target language captions on foreign language students' DVD video comprehension. Foreign Language Annals, 34(5), 439-445.

McLornan, S. \& Guichon, N. (2008). The effects of multimodality on L2 learners: Implications for CALL resource design. System: An International Journal of Education Technology and Applied Linguistics, 36(1), 85-93.

Meng, C. G. C. \& Taib, Y. (2006). Metacognitive instruction in listening for young learners. ELT Journal, 60(3), 222-232.

Morley, J. M. (1991). Listening Comprehension in Second/Foreign Language Instruction. In Marianne Celce-Murcia (Ed.). Teaching English as a Second or Foreign Language (Second Edition). New York: Newbury House.

Nguyen, T. B. H. (2013). English learning strategies of Vietnamese tertiary students. Unpublished doctoral thesis, University of Tasmania, Australia.

Nunan, D. (2010). Teaching English to Young Learners. Anaheim, CA: Anaheim University Press.

O’Malley, J. M., \& Chamot, A. U. (1990). Listening comprehension strategies in second language acquisition. Applied Linguistics, 10(4), 418-437.

Oxford, R. (1990). Language learning strategies: What every teacher should know. Boston, MA: Heinle \& Heinle.

Pujola, J. T. (2002). CALLing for help: Researching language learning strategies using help facilities in a web-based multimedia program. ReCALL, 14(2), 235-262.

Purnomowati, Y. R. (2016). Listening strategies used by ELEP students in listening classes. Unpublished master's thesis. Universitas Kristen Satya Wacana, Indonesia.

Richard, J. C. (2008). Teaching listening and speaking. From theory to practice. New York: Cambridge University Press.

Rost, M. \& Ross, S. (1991). Learner use of strategies in interaction: Typology and teachability. Language Journal, $78(2), 199-221$.

Sanders, R. F. (2005). Redesigning introductory Spanish: Increased enrollment, online management, cost reduction, and effects on student learning. Foreign Language Annals, 38(4), 523-532.

Savigon, S. J. \& Sysoyev, P. V. (2002). Sociocultural strategies for a dialogue of cultures. The Modern Language Journal, 86(4), 508-524.

Scida, E. E., \& Saury, R. E. (2006). Hybrid courses and their impact on student and classroom performance: A case study at the University of Virginia. CALICO Journal, 23(3), 517-531.

Sheorey, R., \& Mokhtari, K. (2001). Differences in the Metacognitive Awareness of Reading Strategies among Native and Non-Native Readers. System, 29(4), 431-449.

Stein, S. K. (1999). Uncovering listening strategies: Protocol analysis as a means to investigate student listening in the basic communication course. Unpublished doctoral dissertation. University of Maryland, Maryland.

Tavakoli, M., Shahraki, S., \& Rezazadeh, M. (2012). The Relationship between Metacognitive Awareness and EFL Listening Performance: Focusing on IELTS Higher and Lower Scorers. The Journal of Language Teaching and Learning, 2, 24-37.

Vandergrift, L. (1997). The comprehension strategies of second language (French) listener. Language Learning, 53(3), 463-496.

Vandergrift, L. (1999). Facilitating second language listening comprehension: acquiring successful strategies. ELT Journal, 53(3), 168-276.

Vandergrift, L. (2003). Orchestrating strategy use: toward a model of the skill second language listener. Language Learning, 53(3), 463-496.

Vandergrift, L. (2007). Recent developments in second and foreign language listening comprehension research. Language Teaching, 40(3), 191-210.

Walker, N. (2014). Listening: The most difficult skill to teach. Encuentro, 23, 167-175.

Wang, K \& Liu, H. (2011). Language acquisition with the help of captions. Studies in Literature and Language, 3(3), 41-45.

Wenden, A. L. (1998). Metacognitive knowledge and language learning. Applied Linguistics, 19(4), 515-537.

Yang, H.Y. (2014). The Effects of Advance Organizers and Subtitles on EFL Learners' Listening Comprehension Skills. CALICO Journal, 31(3), 345-373. 